\title{
РЕКОНСТРУКЦІЯ НАПІРНИХ ГРУНТОВИХ ДАМБ ТА ГРЕБЕЛЬ ВОДОСХОВИЩ У СТАНІ КРИТИЧНОЇ ФІЛЬТРАЦІЇ
}

\section{RECONSTRUCTION OF PRESSURE SOIL DAMS AND DIKES OF RESERVOIRS IN TERMS OF CRITICAL FILTRATION}

\section{Біскуб П.І. доцент, (Луцкий національний технічний університет)}

\section{Biskub P. Associate Professor (Lutsk National Technical University)}

Анотація. Багаторічний термін знаходження земляних гребель під постійним напором, кардинально міняе їхню здатність опору фільтраційному потоку через тіло греблі. Моніторинг показує, щуо збільшення швидкості та обсягу фільтрачіi, має геометричну прогресію, щзо є небезпекою настання критичного моменту та розмиву тіла греблі. Важливим фактором такого явища є те щчо, греблі виконуються дрібнодисперсних грунтів, які з легкістю піддаються вимиву їх часток з тіла греблі. Запропонований метод дає можливість стабілізувати протифільтраиійну стійкість грунтової греблі.

Summary. A great number of water reservoirs is situated in the influence zone of the inhabited and developed downstream areas. The ability to resist the filtration flow through the dam is dramatically changing in time due to their long term stay under the permanent pressure. Continuous physical and chemical diffusion causes the creation of the micro-channels in the dikes which increase the amount of the filtration flow. It has been observed that the the speed and the amount of filtration has been increasing in geometric progression. It brings a danger of the critical moment and erosion of the dike body. It is essential that the dikes are constructed of the finely dispersed soils, which can easily be washed away from the body of the dike. As a result of the studying the interaction of different types of wetted soils with a pressure of water mass showed the inevitability of washing dusty particles with pressure in the period after the arrangement of the dam. In order to replace the space from the washed particles, it is necessary to carry out the mass sealing.

Two options are offered. The first method is based on research, in laboratory conditions, changes in the structure of soil moistened to the limit of fluidity under the influence of its own weight at the release of excess, except for capillary moisture. The second method is based on research with using vibration effects on soil mass with an additional gravitational load to the mass of the test specimen. Researches simulate the proposed method of eliminating the over-normative filtration of the soil dam body in natural conditions.

In the first case, the filtration is reduced by an average of 24 percent. The disadvantage, however, is the considerable amount of time caused by the slow effect of gravity due to the molecular adhesion of the soil.

In the second option of the research the effect of reducing the filtration flow through the dam model is an average of 82 percent and manifests itself during the time of 
the experiment, that is, instantly. This method confirms its effectiveness in conditions that prevent long-term emptying of the reservoir, which is present in most cases.

The suggested method allows for the stabilization of the filtration stability of the soil dikes.

Ключові слова: грунтові дамби, греблі, фільтрачійна стійкість

Keywords: soil dams, dikes, filtration stability

Вступ. Містобудівні вимоги до освоєння територій передбачають захист від окремих несприятливих факторів впливу на зону забудови, таких як затоплення. Крім того, багато освоєних територій уже знаходяться у зоні ризику затоплення аварійним руйнуванням гребель водосховищ, що знаходяться в поймі річок вище освоєної території. В переважній більшості такі дамби та греблі виконуються земляними, 3 місцевого грунту, що підтверджується економічною доцільністю.

Економічна складова будівництва спонукає до влаштування гребель та дамб $з$ місцевого грунтового матеріалу. Оскільки грунти за своїм складом мають далеко неоднакові характеристики, то для цілей водоутримання вони повинні мати відповідні значення коефіцієнтів щеплення, фільтрації та інфільтрації, гранулометричний склад та щільність.

Досягти бажаних позитивних характеристик грунту для формування тіла греблі в більшості випадків неможливо через відсутність такого на місці будівництва, а доставка на значні відстані економічно невигідна.

В зв'язку з тим, такі греблі за значний період експлуатації змінюють свої характеристики стосовно опору фільтрації.

\section{Аналіз відомих досліджень.}

Проблема росту об'єму фільтрації тіла греблі водосховищаакумулятора Хмельницької атомної станції, м. Остріг Рівненської області, яка зафіксована в 2008 році, стимулювала до досліджень процесу та пошуку способу його ліквідації. Подібні дослідження проводяться по завданню Капітального ремонту греблі та поліпшення технічного стану водойми в с. Князівка Князівської сільської ради Путивльського району Сумської обл. Багаторічні спостереження за поведінкою кривої депресії фільтраційного потоку ведуться за допомогою ряду п'єзометрів, встановлених в тілі греблі по напрямку фільтраційного потоку (впоперек греблі). П'єзометри виконують 3 металевих труб діаметром 25-50мм 3 влаштуванням перфорації, яка ззовні захищена фільтраційним матеріалом та гравійною обсипкою (рис.1.).

У грунтових греблях, в зв'язку з безперервним процесом фізичної та хімічної дифузії утворюються мікроканали, які сприяють збільшенню величини фільтраційного потоку, що підтверджується дослідами 3 механікою дрібнодисперсних грунтів. Встановлені п'єзометри по шляху фільтраційного потоку за період спостережень показують зміну 
конфігурації кривої депресії, що підтверджується дослідами. Крім того, неоднорідність грунтової маси для формування греблі, значні протяжності та людський фактор при їх влаштуванні, не виключають потрапляння в тіло греблі органічних складових грунту, який з часом розкладається на складові, що сприяють фільтраційному потоку.

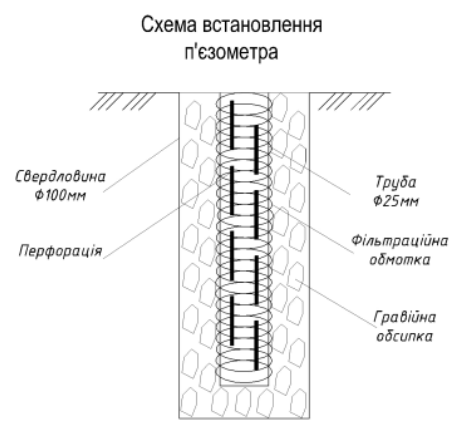

Рис. 1. Схема встановлення п’езометра в тілі греблі.

Як правило, кривизна депресії в тілі грунтової греблі з часом випрямляється, що свідчить про зменшення опору тіла фільтраційному потоку. Схема встановлення п’єзометрів для спостереження за поведінкою зміни фільтраційного потоку в тілі земляної греблі за період довготривалої експлуатації наведена на рис. 2.

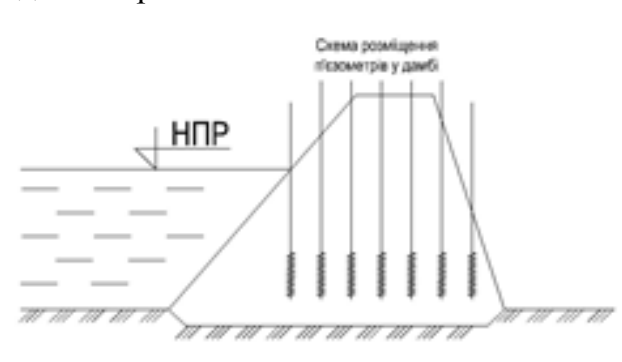

Рис. 2. Схема розміщення п’єзометрів в тілі греблі.

Зовнішньою ознакою такого явища $є$ підняття відмітки змоченої частини низового укосу та збільшення об'єму фільтрованого стоку через греблю. Об'єм фільтрованого стоку зростає за геометричною прогресією через те, що при збільшенні швидкості та об'єму наростає процес фізичної та хімічної дифузії грунтової маси. Дифузія збільшує мікроскопічні канали і сприяє втраті опору тіла греблі до фільтрації.

Таке явище $\epsilon$ небезпечним, тому що в кінцевому результаті може відбутись зростання об'єму та швидкості фільтраційного потоку до розмивного рівня. 
Внаслідок такого явища крива депресії фільтраційного потоку спрямляється. Вихідний потік у нижньому бьєфі піднімається, що зменшує опір тіла греблі потоку. За рахунок такого явища фільтраційний потік збільщується в геометричній прогресії (рис. 3).

За рахунок насичення водою більшої частини тіла греблі, грунт знаходиться в підвішеному стані, що сприяє проходженню фільтраційного потоку через розрідження i зменшення піi ваги. Саме тому, всі без виключення грунтові греблі втрачають свої початкові протифільтраційні $з$ часом експлуатації.

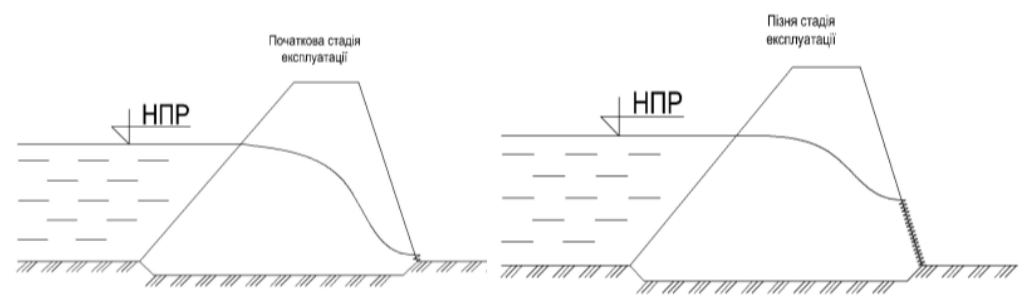

Рис. 3. Зміна форми кривої депресії фільтраційного потоку за період експлуатації

На зміну форми кривої депресії фільтраційного потоку в тілі греблі впливає режим експлуатації водосховища.

При циклічному наповненні водосховища або значних коливаннях нормально підпертого рівня (НПР), зміни кривої депресії значно менші, ніж при постійному високому рівні відмітки води водосховища.

Це пояснюється тим, що після опорожнення водосховища насичене водою тіло дамби самоущільнюється завдяки інфільтрації (вертикальному опусканню води в тілі дамби) та ліквідації підвішеності грунтової маси греблі.

В греблях 3 постійним підпертим рівнем води водосховища такі фактори відсутні, тому фільтраційні потоки з часом збільшуються.

В будівництві, для збільшення щільності основ під будівлі чи штучно створених основ насипом, здійснюється метод насичення водою грунтової маси $з$ послідуючим, після підсихання, ущільненням методом укатки або утрамбування.

Якщо навіть не використовувати штучний метод ущільнення, то за рахунок власної ваги певна товща грунту буде ущільнюватись після звільнення від надлишкової води інфільтрацією.

Це викликано тим, що при насиченні водою значно зменшуються коефіцієнти внутрішнього тертя та зчеплення і тому зростає границя текучості. Крім того, маса тіла греблі збільшується за рахунок насиченості водою та одночасно втрата підвішеності грунтової маси збільшує зусилля самоущільнення. 
Важливим фактором є співпадіння, в даному випадку, вектора потоку інфільтрації з вектором дії маси грунту, що сприяє ущільненню. Крім того, слід брати до уваги те, що для кожного виду грунту тіла греблі існують різні градієнти напору та критичні швидкості руху фільтраційної води, які являються початком суфозії та контактного розмиву.

При цьому слід враховувати коефіцієнти фільтрації, що мають значні відхилення в різних грунтів.

Прикладом є:

- глини, пісок пилуватий $-0,5 \div 2$ м/добу;

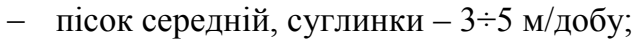

- пісок крупний $-10 \div 20$ м/добу.

Оскільки швидкість фільтрації в кінцевому результаті виражається об'ємом потоку на виході за певний час, то потрібно встановити водомір обліку фільтраційного потоку на невеликому /до 10м/ контрольному відрізку виходу фільтраційного потоку. Збільшення об'єму фільтраційного потоку за однаковий період часу з роками експлуатації $\epsilon$ свідченням втрати протифільтраційної стійкості греблі. Як відомо, швидкість та об'єм фільтраційного потоку за роки експлуатації зростає за геометричною прогресією, що приближує до стану контактного розмиву, який залежить від складу грунту тіла греблі, але в кінцевому етапі наступає.

\section{Постановка мети і задач досліджень.}

Метою досліджень $€$ пошук можливості ліквідації утворених механічною та хімічною дифузією мікропор у тілі греблі з використанням гравітації.

\section{Методика впровадження досліджень.}

Для цього (за можливості) слід опорожнити водосховище, або максимально понизити рівень «НПР». Далі, за певний період після звільнення тіла греблі від надлишкової води, через інфільтрацію, що залежить від висоти греблі та складу грунту, здійснити навантаження на гребінь греблі з використанням великовагових віброкатків.

Укатування має бути здійснене з мінімальною прохідною швидкістю та малою частотою вібрації, для збільшення амплітуди коливань для проникнення їх на значну глибину грунтової маси.

Таким чином, за принципом віброваної укладки бетонної суміші, здійснюватиметься ущільнення тіла греблі за рахунок гравітаційного переміщення в поєднанні з вібруванням, яке зменшує молекулярне зчеплення грунту, що сприяє ущільненню.

У випадку неможливості використання віброкатків через наявність асфальтового покриття на гребені греблі, може бути застосовано метод вібрування рухом групи великовагових автомобілів 3 повним завантаженням типу «КРАЗ», «БелАЗ», «Татра» 3 влаштуванням штучних нерівностей проїзду. 
Ефект такого способу буде досягнуто за рахунок мінімальної відстані між автомобілями, що дасть можливість накладання амплітуд коливань $\mathrm{i}$ взаємного їх підсилення.

Результати досліджень та висновок. Цей метод є досить вагомою альтернативою, оскільки всі інші, такі як: утворення діафрагм, екранів, суцільне кріплення верхових укосів чи влаштування ядра греблі, $є$ досить затратними. Це особливо досить ефективний метод при наявності в тілі греблі органічних складових грунту, оскільки утворені від гниття порожнини будуть заповнені мінеральними частками породи, які перешкоджають фільтрації.

\section{References}

DBN V.2.4-20:2014 Earth Dams. Methods of conducting field surveys of dams and protective water management dams.

2. Determination of the technical condition of earth piezometers. https://prozorro.gov.ua > > UA-2017-08-0.

3. Reconstruction of the hydrotechnic structure and earth dam. https://zakupki.prom.ua > > UA-20.

4. Tertsagi K. Soil mechanics theory. - Moscow: Nedra, 1993. - 245 p.

5. Tsytovich N.A. Soil mechanics: A brief course. - Moscow: Vysshaya Shkola, 1993. $-288 \mathrm{p}$.

6. Sidorov N.N. Modern methods for determining the characteristics of the soil mechanical properties/ in Sidorov N., Sipidin V.P. - Leningrad: Lentechstroyizdat, 1972. $-136 \mathrm{p}$.

7. Soil mechanics, basics and fundamentals: a textbook / L.M. Shutenko, O.G. Rud, O.V. Kichayeva. - Kharkiv: O.M. Bekhetov National City Management University. Kharkiv

\section{Список використаної літератури:}

1. ДБН В.2.4-20:2014 Греблі з грунтових матеріалів. Методика проведення натурних обстежень земляних гребель $\mathrm{i}$ захисних дамб водогосподарського призначення. Посібник до ВБН В.2.4-33-2.3-03-2000

2. Визначення технічного стану п'єзометрів земляної греблі https://prozorro.gov.ua > tender > UA-2017-08-0.

3. Реконструкція гідротехнічної споруди та земляної греблі https://zakupki.prom.ua > gov > tenders > UA-20.

4. Терцаги К. Теория механики грунтов / К. Терцаги ; пер. с англ. ; под. ред. Н. А. Цитовича. - М. : Недра, 1993. - 245 с.

5. Цытович Н. А. Механика грунтов: краткий курс / Н. А. Цытович. - М. : Высшая школа, 1983. - 288 с.

6. Сидоров Н. Н. Современные методы определения характеристик механических свойств грунтов / Н. Н. Сидоров, В. П. Сипидин. - Л. : Лентехстройиздат, 1972. - $136 \mathrm{c.}$

7. Механіка грунтів, основи та фундаменти: підручник / Л. М. Шутенко, О. Г. Рудь, О. В. Кічаєва та ін. ; за ред. Л. М. Шутенка ; пер. $з$ рос. ; Харків. нац. ун-т міськ. госп-ва ім. О. М. Бекетова. - Харків : 